\title{
Studi Kelayakan Pendirian Industri Kecil Pakan Ikan di Calingcing-Cianjur
}

\author{
Feasibility Study of the Establishment of Small Scale Fish Feed Industry
}

\author{
Syamsu Darman ${ }^{1 *}$, Fransiska R. Zakaria ${ }^{2 \sharp}$, dan Tjahja Muhandri ${ }^{2 \sharp}$ \\ ${ }^{1}$ Kementerian Kelautan dan Perikanan \\ Gedung Mina Bahari III lt.9 Jl. Medan Merdeka Timur No.16, Jakarta Pusat 10110 \\ ${ }^{2}$ Departemen Ilmu dan Teknologi Pangan, Fakultas Teknologi Pertanian, Institur Pertanian Bogor \\ \#Jl. Kamper, Kampus IPB Darmaga, 16680
}

\begin{abstract}
ABSTRAK
Mahalnya harga pakan komersial diatasi dengan pembuatan pakan ikan yang memanfaatkan bahan baku lokal. Pengunaan bahan baku Hasil uji analisis proksimat dengan protein $28,84 \%$, lemak 8,66\%, abu 10,70\%, serat kasar 4,56\% dan bahan ekstrak tanpa nitrogen $47,24 \%$ yang merupakan hasil temuan BPPBAT Sempur. Tujuan kajian ini: (1) untuk menganalis kelayakan usaha pendirian industri kecil pakan ikan di Calincing Cianjur secara deskriftif dilihat dari aspek potensi pasar dan pemasaran, sumberdaya manusia, manajemen dan teknik dan teknologi produksi, (2) Menganalisis kelayakan usaha dari aspek Finansial (NPV atau Net Present Value, IRR atau Internal Rate of Return, net B/C atau Benefit/Cost, PBP atau Payback Periode). Bahan baku pakan ikan nila (Orechromis sp) sesuai formulasi yang diterapkan BBAPT Sempur Bogor, yaitu komposisi bahan baku terdiri dari tepung ikan lokal $20 \mathrm{~kg}$, tepung bungkil kedelai $28 \mathrm{~kg}$, dedak halus $33 \mathrm{~kg}$, minyak ikan $2 \mathrm{~kg}$, tepung tapioka $3 \mathrm{~kg}$, minyak nabati 1 $\mathrm{kg}$ dan vitamin top mix $2 \mathrm{~kg}$ dan mineral $1 \mathrm{~kg}$. Proses produksi pakan ikan sebagai berikut (1) penerimaan dan penyimpanan bahan baku, (2) sortasi bahan baku, (3) penyaringan bahan baku, (4) penimbangan bahan baku dan formulasi, (5) pencampuran bahan baku, (6) pemberian uap panas (7) pencetakan adonan, (8) pengeringan, serta (9) pengepakan dan pengarungan. Potensi permintaan akan pakan ikan nila di wilayah Cianjur 149.321,28 ton per tahun dan wilayah Ciranjang 25.704,8 kg per tahun, Biaya investasi pendirian pabrik pakan ikan dengan kapasitas produksi 1 ton per hari atau 300 ton per tahun Rp1.755.800.000. Nilai Biaya pokok produksi pakan ikan Rp5.764/kg dengan harga jual pakan ikan Rp6.800/kg memperoleh margin rata-rata Rp693/kg. Nilai-nilai kriteria kelayakan usaha adalah NPV Rp.452.852.260,073 pada tingkat diskonto $14 \%$ per tahun (layak), IRR 25,04\% (layak), Net B/C pada tingkat diskonto 14\% per tahun diperoleh nilai 1,45 (layak), dan PBP 3,09 atau 3 Tahun, 33 hari (layak).
\end{abstract}

Kata kunci: bahan baku lokal, pakan ikan nila, studi kelayakan

\begin{abstract}
Problems about high price of fish pellets could overcome by producing fish pellets with local ingredients. The objectives of this study were: (1) to analyze the feasibility of small fish pellets industry establishment in Calincing, Cianjur. Aspect of potential market, marketing, human resources, management technique, and production technology are analyzed descriptively; (2) Analyze financial feasibility aspect (NPV orNet Present Value, IRR or Internal Rate of Return, net B/C or Benefit/Cost, and PBP or Payback Periode). Ingredients of pellets which used for Nila Tilapia (Oreochromis sp.) had according to standard formula of BBAPT Sempur, Bogor. The composition were $20 \mathrm{~kg}$ of local fish meal, $28 \mathrm{~kg}$ soybean meal, $33 \mathrm{~kg}$ rice bran, $10 \mathrm{~kg}$ palm karnel meal, $2 \mathrm{~kg}$ of fish oil, $3 \mathrm{~kg}$ tapioca flour, $1 \mathrm{~kg}$ vegetable oil, $2 \mathrm{~kg}$ of top mix vitamin and $1 \mathrm{~kg}$ of mineral. The process of fish pellets production as follows: (1) receipts and storage of ingredients, (2) sorting, (3) screening, (4) weighing and formulation, (5) mixing, (6) hot steaming the ingredients, (7) pelleting, (8) drying; and (9) packing. The potential demand for Tilapia fish

\footnotetext{
*) Korespondensi:

Kementerian Kelautan dan Perikanan, Gedung Mina Bahari III lt.9 Jl. Medan Merdeka

Timur No.16, Jakarta Pusat 10110. e-mail: syamsu_pmp@yahoo.com
} 
pellets in Cianjur were 149,321.28 tons per year and 25,704.80 kg per year in Ciranjang region. The investment cost for the establishment of fish pellets industry which production capacity of 1 ton per day or 300 tons per year was Rp1,755,800,000. Value cost for fish pellets production per kg was Rp5.764 with selling price was Rp6.800/ $\mathrm{kg}$, it got average margin as Rp693/kg. Feasibility criteria value showed that NPV was Rp452.852.260,073 at a discount rate of $14 \%$ per year (decent), IRR was $25,04 \%$ (decent), Net B/C was 1,45 (decent), and PBP was 3,09 or 3 years, 33 days (worthy).

Key words: feasibility study, local ingredients, tilapia pellets

\section{PENDAHULUAN}

Pada budidaya ikan intensif pakan buatan berkontribusi sangat besar dalam struktur biaya produksi sekitar 40-89\% (Suprayudi, 2010). Pakan merupakan salah satu komponen input yang penting karena disamping dapat menentukan koefisien teknis budidaya seperti pertumbuhan (SGR), kelangsungan hidup (survival rate atau $\mathrm{SR}$ ), konversi pakan (feed conversion ratio atau FCR), biomass dan waktu budidaya, pakan juga merupakan beban dalam lingkungan budidaya akibat limbah yang dihasilkan ikan, baik berasal dari pakan yang tidak termakan, tidak dicerna maupun limbah metabolisme. Salah satu kunci utama dalam pembuatan pakan yang tepat adalah formulasi pakan yang dapat memenuhi persyaratan kebutuhan nitrisi bagi ikan untuk pertumbuhan tetapi juga dapat mengurangi pencemaran yang diakibatkan tidak efisiennya penggunaan protein dalam pakan ikan (Asminatun, 2010). Semakin sempitnya perairan untuk budidaya ikan dan meningkatnya pencemaran air, maka pada masa mendatang budidaya konvensional harus diubah menjadi budidaya intensif (Sirakov \& Ivancheva, 2008).

Penggunaan pakan komersial dalam budidaya ikan air tawar mulai meningkat semenjak akhir tahun 1980 di Jawa Barat, seiring dengan berkembangnya kolam air deras dan Keramba Jaring Apung (KJA) di Waduk Cirata. Saat ini semua pembudidaya sangat fanatik terhadap pakan untuk peningkatan pertumbuhan dan produksi. Hingga saat ini tercatat lebih dari 12 pabrik pakan tersebar di sentra produksi budidaya ikan di Jawa, Lampung dan Sumatera Utara (Indrajaya, 2010). Hampir semua bahan baku pakan diimpor. Tepung ikan, tepung tulang dan tepung bungkil kedelai umumnya digunakan sebagai sumber protein hewani dan nabati. Pada tahun 2004-2009 impor tepung ikan meningkat dari 28.620.57 ton menjadi 47.518.97 ton (kenaikan sekitar 15,14\%) dengan rataan harga 916.12 US\$ per ton (KKP, 2010). Tepung ikan impor ini yang diduga menjadi penyebab tingginya harga pelet ikan di Indonesia. Harga pakan komersial saat ini berkisar Rp6.800-8.800 per $\mathrm{kg}$, tergantung komposisi mutunya. Permasalahan yang sering menjadi kendala yaitu penyediaan pakan buatan ini memerlukan biaya yang relatif tinggi, bahkan mencapai $60-70 \%$ dari komponen biaya produksi (Emma, 2006).

Penggunaan bahan baku lokal diharapkan dapat menurunkan biaya produksi pelet ikan Salah satu alternatif pengganti/pengurangan bahan baku pakan tepung ikan impor dengan menggunakan bahan baku berasal dari tepung ikan lokal yang diolah dari limbah industri perikanan, ikan rucah dan ikan yang sudah mengalami kemunduran mutu. Pengujian pakan pembesaran ikan nila (Oreochromis sp) dengan berbasis bahan baku lokal terbukti memberikan pertumbuhan yang baik sebesar $2,62 \%$ dengan menghasilkan nilai konversi pakan sebesar 1,521,61 (Samsudin et al, 2012). Penelitian ini berupaya untuk mengkaji kelayakan pendirian industri pakan ikan nila dengan formula yang dikembangkan Balai Pengembangan Produksi Budidaya Air Tawar atau BPPBAT (Sunarno et al, 2012). Pakan ikan berdasarkan konsep protein ideal merupakan pakan yang efisien karena komposisi asam amino yang diperlukan sama dengan yang diperlukan oleh ikan. Oleh karena itu, pakan tersebut dapat meningkatkan pertumbuhan dan tidak mencemari lingkungan (Asminatun, 2010). Kebutuhan asam amino esensial sangat penting untuk menentukan komposisi kebutuhan pakan ikan (Mai et al, 2006).

Tujuan kajian ini adalah (1) Menganalisis kelayakan usaha pendirian industri kecil pakan ikan nila di Calingcing Kec. Ciranjang, Kabupaten Cianjur secara deskriptif dilihat dari aspek potensi pasar dan pemasaran, sumberdaya manusia, manajemen, teknik dan teknologi produksi; (2) Menganalisis kelayakan usaha dilihat dari aspek finansial (NPV, IRR, Net B/C, PBP). 


\section{METODE PENELITIAN}

Kajian dilakukan dengan metode sampling yang digunakan adalah Non-Probability Sampling dengan teknik purposive sampling, berdasarkan Sugiyono (2009), dimana teknik penentuan contoh dengan pertimbangan tertentu atau secara sengaja. Lokasi penelitian ditentukan secara sengaja (purposive) yakni wilayah Desa Calingcing Kecamatan Ciranjang, Kabupaten Cianjur. Untuk menganalisis kelayakan pembuatan pabrik pakan dilakukan analisis dengan metode analisis secara deskriptif, dimana metode analisisnya terdiri dari analisis aspek non finansial dan analisis aspek finansial.

Analisis aspek non finansial adalah menganalisis secara dekriptif kelayakan bisnis dilihat dari: Aspek pasar, Aspek pemasaran, Aspek teknik dan teknologi, Aspek manajemen, Aspek sumberdaya manusia, Aspek Proses Produksi Pengolahan Pakan, Aspek Teknologi Mesin dan Peralatan Produksi, sedangkan analisis aspek finansial yang diukur antara lain Net present value (NPV), Internal Rate of Return (IRR), Net Benefit Cost Ratio (Net B/C), dan Pay back Period.

\section{HASIL DAN PEMBAHASAN}

\section{Aspek Non Finansial}

\section{Aspek Pasar}

Jumlah produksi ikan nila di wilayah Cianjur 93.325,80 ton jika dikalikan dengan food conversion ratio $(\mathrm{FCR})$ rataan untuk $1 \mathrm{~kg}$ ikan nila yaitu 1,6-1,8 Feed Conversion Ratio (FCR) maka kebutuhan pakan ikan di wilayah Cianjur 149.321,28 ton per tahun. Untuk daerah Ciranjang sendiri dengan jumlah produk 16.065,5 ton per tahun dikalikan FCR 1,6, maka kebutuhan pakannya $25.704,8$ ton per tahun.

\section{Aspek Pemasaran}

Terkait dengan aspek pemasaran kebijakan harga, maka harga pakan ikan yang ditawarkan harus di bawah atau sama dengan Rp6.800/kg untuk pakan ikan nila. Serta posisi pasar dan tempat usaha di Ciranjang merupakan tempat yang sertrategis untuk usaha. Selain itu diperlukan langkah promosi agar konsumen yang telah mengkonsumsi pakan pabrik industri besar beralih untuk membeli pakan pabrik industri rumah tangga/kecil.

\section{Aspek Teknis dan Teknologi}

Bahan baku pakan ikan nila (Orechromis sp) sesuai formulasi yang diterapkan BBAPT Sempur Bogor (2011) yaitu komposisi bahan baku terdiri dari tepung ikan lokal $(20 \mathrm{~kg})$, tepung kedelai $(25 \mathrm{~kg})$, dedak halus $(45 \mathrm{~kg})$, minyak nabati $(1 \mathrm{~kg})$, minyak ikan $(3 \mathrm{~kg})$, tepung tapioka $(3 \mathrm{~kg})$ dan vitamin $(2 \mathrm{~kg})$. Proses produksi pakan ikan sebagai berikut: (1) penerimaan dan penyimpanan bahan baku (2) sortasi bahan baku (3) penyaringan bahan baku (4) penimbangan bahan baku dan formulasi (5) pencampuran bahan baku (6) pemberian uap panas (7) pencetakan adonan (8) pengeringan serta (9) pengepakan dan pengarungan. Kandungan pakan, terutama protein dapat ditingkatkan dengan menambahkan porsi tepung ikan, dedak dan bahan lain yang mengandung protein tinggi (Zaenuri et al, 2010).

Secara teknis rencana produksi pakan ikan nila berupa pellet tenggelam $1.000 \mathrm{~kg}$ per hari dengan susut maksikmal 8,9\% yang berarti setiap $1.000 \mathrm{~kg}$ bahan baku per hari menghasilkan berat kering pelet 91,06 kg/88 kgi. Penggunaan teknologi semi modern, dimana mesin yang digunakan cukup memproduksi $1.000 \mathrm{~kg}$ per hari. Komposisi bahan baku menggunakan bahan baku hasil dari BPPBAT Sempur Bogor dengan hasil uji test analisis proksimat sebagai berikut: protein $28,84 \%$, lemak $8,66 \%$, abu $10,7 \%$, serat kasar $4,56 \%$ dan bahan ekstrak tanpa nitrogen $47,24 \%$.

\section{Aspek Sumber Daya Manusia}

Komposisi, jumlah dan spesifikasi tenaga kerja/karyawan dapat dengan mudah direkrut di sekitar lokasi pabrik. Jumlah tenaga kerja yang diperlukan sebanyak 4 orang. Untuk meningkat mutu sumber daya akan berkerjasama dengan Kementerian Kelautan dan Perikanan, serta dinas terkait dalam bentuk pelatihan-pelatihan.

\section{Aspek Manajemen}

Secara manajerial, usaha pabrik pakan ikan nila dapat dilaksanakan, dengan tetap melaksanakan rencana usaha sesuai dengan analisis dari aspek non finansial.

\section{Aspek Finansial}

Kebutuhan atau permintaan akan pakan ikan nilai di wilayah Cianjur 149.321,28 ton per tahun dan wilayah Ciranjang 25.704,8 merupakan pasar yang potensial untuk dimasukan dalam usaha pembuatan pakan ikan. Untuk itu 
kebutuhan finansial akan dibahas secara analisa finansial dan diinterprestasikan secara deskriptif.

\section{Asumsi yang digunakan}

Periode Analisis Proyek usaha pakan ikan yaitu 5 tahun. Waktu produksi efektif selama 1 tahun yaitu 300 hari. Kapasitas produksi 1 ton per hari atau 300 ton per tahun. Produksi pakan ikan yang terjual 300 ton per tahun. Harga pakan ikan nila yang dijual maksimal Rp6.00 per kg. Kebutuhan Investasi meliputi Perijinan, tanah bangunan, peralatan produksi, dan fasilitas pemasaran. Biaya dan harga jual tetap selama periode analisis, yakni 5 Tahun (60 bulan). Pinjaman untuk modal kerja Rp500.000.000 dengan lama pinjaman selama 3 tahun (36 bulan). Discount faktor (bunga pinjaman) yang digunakan $12 \%$ per tahun (bunga menurun).

Kebutuhan Modal

Modal Jumlah dana investasi pembuatan pakan ikan selama operasional 1 tahun proyek Rp1.955.800.000 dengan proporsi sumber modal dana sendiri 74,4\% atau Rp1.455.800.000 dengan rincian Rp277.600.000 sebagai modal investasi dan Rp1.178.200.000 sebagai modal operasional, sedangkan proporsi modal pinjaman $25,6 \%$ atau Rp500.00.000 untuk membantu modal operasional.

\section{Analisis Bunga Kredit}

Pinjaman Rp500.000.000 dengan bunga 14\% menurun dan jangka waktu kredit 3 tahun maka total angsuran tahun ke-1 Rp225.972.222, tahun kedua Rp202.638.889 dan tahun ketiga Rp179.305.556.

\section{Rencana Pendapatan Produksi}

Penerimaan produksi pakan ikan diperoleh dari total produksi sebesar $300.000 \mathrm{~kg}$ per tahun. Dengan harga jual pakan Rp6.800/kg diperoleh pendapatan kotor/omset per tahun Rp2.040.000.000.

\section{Analisis Finansial Kelayakan Usaha}

\section{Proyeksi Laba/Rugi}

Diketahui bahwa selama umur usaha pakan ikan 5 tahun diperoleh rataan laba kotor Rp361.800.000, sedangkan untuk rataan laba bersih setelah dikurangi komponen biaya tak terduga $2 \%$, biaya pinjaman, biaya penyusutan, dan biaya pajak $10 \%$ diperoleh rataan lama bersih per tahun Rp183.102.964 atau sama dengan rataan laba bersih per bulan Rp15.258.580 dan rataan profit margin $8,98 \%$.

\section{BEP Usaha}

BEP usaha untuk pakan ikan pada tahun ke-1 diperoleh BEP usaha Rp6.395 per kg, sehingga dengan harga jual pakan Rp6.800/kg masih terdapat margin Rp405/kg. BEP usaha pada tahun ke-4 atau setelah lepas dari kredit maka BEP usaha Rp5.764/kg, sehingga pada tahun ke-4 diperoleh margin Rp1.036/kg. Rataan BEP usaha pakan ikan adalah $\mathrm{Rp} 6.107 / \mathrm{kg}$, sehingga rataan margin BEP usaha dengan harga jual pakan ikan Rp6.800/kg memperoleh margin Rp693/kg.

\section{NPV}

Hasil analisis finansial yang dilakukan untuk periode lima tahun diperoleh NPV Rp452.852.560,075 pada tingkat diskonto $14 \%$ per tahun. Nilai NPV positif menunjukkan rencana usaha pabrik pakan ikan tersebut layak dilaksanakan.

\section{IRR}

Analisis finansial yang dilakukan untuk periode lima tahun diperoleh IRR 25,04\%. Nilai IRR tersebut, jauh lebih besar dibandingkan dengan suku bunga $14 \%$ per tahun. Artinya, rencana usaha pabrik pakan ikan tersebut layak dilaksanakan

\section{Net B/C}

Nilai Net B/C pada tingkat diskonto sebesar $14 \%$ per tahun diperoleh nilai 1,45 . Artinya, usaha pabrik pakan ikan tersebut memiliki manfaat yang lebih besar dari biaya yang diperlukan, sehingga rencana usaha pabrik pakan ikan tersebut layak dilaksanakan.

\section{PBP}

Hasil perhitungan PBP usaha, diperoleh nilai 3,09 atau setara dengan masa pengembalian selama 3 Tahun, 32 hari. Artinya, usaha pabrik pakan ikan memiliki masa pengembalian investasi relatif singkat dan lebih cepat dibanding umur rencana investasi usaha pembuatan pabrik pakan ikan, sehingga rencana usaha pabrik pakan ikan tersebut layak dilaksanakan. Hasil Perhitungan untuk PBP kredit, diperoleh nilai 0,75 atau kurang dari 1 tahun, yang artinya jika keuntungan usaha dibayarkan sepenuhnya untuk membayarkan kredit maka pada tahun pertama kredit tersebut sudah dapat dilunasi 
secara penuh. Sehingga dapat disimpulkan bahwa usaha investasi pakan ikan layak untuk dibiayai melalui modal pinjaman dengan tingkat bunga $14 \%$.

\section{KESIMPULAN}

Peluang pasar untuk pakan ikan skala industri kecil masih terbuka, namun hal ini perlu didukung dengan mutu dan harga yang mampu bersaing dengan pakan komersial. Pasar yang sangat potensial untuk dimasuki adalah pasar konsumen dan pasar industri/kelompok pembudidaya ikan. Harga pakan ikan yang ditawarkan harus dibawah pakan konvensional yang sudah ada. Dengan harga pakan Rp6.800/ $\mathrm{kg}$ masih terdapat margin Rp693/kg. Rencana produkasi pakan ikan nila berupa pellet terapung $1.000 \mathrm{~kg}$ per hari dengan formulasi pakan dari BPPBAT Sempur sangat layak untuk diusahakan dengan Hasil uji analisis proksimat dengan protein $28,84 \%$, lemak $8,66 \%$, abu $10,70 \%$, serat kasar $4,56 \%$ dan bahan ekstrak tanpa nitrogen $47,24 \%$. Pakan ini sudah memenuhi standar (SNI 01-7242-2006), maka layak dijual kepada konsumen. Sehingga pakan ini sudah memenuhi standar (SNI 01-7242-2006) layak untuk dijual kepada konsumen. Berdasarkan komposisi, jumlah dan spesifikasi tenaga kerja/karyawan dapat dengan mudah direkrut di sekitar lokasi pabrik. Jumlah tenaga kerja yang diperlukan 4 orang.

Jumlah dana keseluruhan invetasi untuk pembuatan pakan ikan selama operasional 1 tahun proyek adalah Rp1.955.800.000 dengan proporsi sumber modal dana sendiri sebesar 74,4 persen atau Rp1.455.800.000, sedangkan proporsi modal pinjaman $25,6 \%$ atau Rp500.000.000. Nilainilai kriteria kelayakan usaha adalah NPV Rp452.852.260,073 pada tingkat diskonto $14 \%$ per tahun (layak), IRR 25,04\% (layak), Net B/C pada tingkat diskonto sebesar $14 \%$ per tahun diperoleh nilai 1,45 (layak), dan PBP 3,09 atau 3 Tahun, 33 hari (layak). Net B/C pada tingkat diskonto $12 \%$ per tahun diperoleh nilai 1,58 (layak) dan PBP 2,78 atau 2 Tahun, 284 hari (layak).

\section{DAFTAR PUSTAKA}

Allan et al. 2000. Replacement of Fish Meal in Diets for Australian Silver Perch,Bidyanus bidyanus: I. Digestibility of Alternative Ingredients. Aquaculture.
Asminatun. 2010. Pembuatan Pakan Ikan Berdasarkan Konsep Protein Ideal yang Ramah Lingkungan. Jurnal UI Untuk Bangsa Seri Kesehatan, Sains, dan Teknologi, 1: 70-78.

Emma, Z. 2006. Studi Pembuatan Pakan Ikan dari Campuran Ampas Tahu, Ampas Ikan, Darah Sapi Potong, dan Daun Keladi yang Disesuaikan dengan Standar Mutu Pakan Ikan. Jurnal Sains Kimia 10: 40-45.

Furuichi M. 1988. Dietary Requirements: Carbohydrates. di dalam: Watanabe T.Fish Nutrition and Marineculture. Departement of Aquatic Biosciences Tokyo University of Fishes. Tokyo: p 1-77.

KKP. 2010. Data Impor Tepung Ikan. Kementerian Kelautan dan Perikanan.

Mai, K., L. Zhang, Q. Ai, Q. Duan, C. Zhang, H. Li, J. Wan \& Z. Liufu. 2006. Dietary lysine of juvenile japanese seabass Lateolabrax japonicas. Aquaculture, 258: 535-542.

Samsudin, Sulhi, Sunarno. 2012. Pengembangan Pakan untuk Budidaya Nila Best Berbahan Baku Lokal Secara Komersil di Kabupaten Agam dan Kabupaten Pandeglang. Tesis. Balai Penelitian dan Pengembangan Budidaya Air Tawar Bogor.

Sirakov, I. \& E. Ivancheva. 2008. Influence of stocking density on the growth performance of rainbow trout and brown trout grown in recirculation system. Bulgaria Journal of Agriculture Science, 14(2): 150-54.

Sugiyono. 2009. Metode Penelitian Kuantitatif, Kualitatif dan R\&D. Alfabeta, Bandung.

Sunarno, Sulhi, Samsudin, Heptarina. 2012. Petunjuk Teknis Teknologi Pakan Ikan: Ekonomis dan Efisien Berbasis Bahan Baku Lokal. IPB Press Bogor.

Suprayudi M, A. 2010. Bahan baku pangan lokal : tantangan dan harapan akuakultur Indonesia. Simposium Nasional Bioteknologi Akuakultur III. IPB International Convention Center. Bogor

Umar. 2007. Studi Kelayakan Bisnis. Jakarta: Gramedia Pustaka Utama.

Watanabe T. 1988. Fish Nutrition and Marineculture.Departement of Aquatic Biosciences, Tokyo University of Fisheries, JICA. 